Article

\title{
Formation and Outburst of the Toguz-Bulak Glacial Lake in the Northern Teskey Range, Tien Shan, Kyrgyzstan
}

\author{
Mirlan Daiyrov ${ }^{1, *(\mathbb{D}}$, Chiyuki Narama ${ }^{2} \mathbb{C}$, Andreas Kääb ${ }^{3}$ and Takeo Tadono 4 (D) \\ 1 Central-Asian Institute for Applied Geosciences (CAIAG), Bishkek 720027, Kyrgyzstan \\ 2 Program of Field Research in the Environmental Sciences, Niigata University, Niigata 950-2181, Japan; \\ narama@env.sc.niigata-u.ac.jp \\ 3 Department of Geosciences, University of Oslo, 0316 Oslo, Norway; a.m.kaab@geo.uio.no \\ 4 Japan Aerospace Exploration Agency (JAXA), Tsukuba 305-8505, Japan; tadono.takeo@jaxa.jp \\ * Correspondence: mirlan085@gmail.com
}

Received: 17 September 2020; Accepted: 9 November 2020; Published: 19 November 2020

\begin{abstract}
In Kyrgyzstan, outburst flood disasters from glacial lakes are increasing. An example is the sudden drainage on 8 August 2019 of the Toguz-Bulak glacial lake in the Tosor river basin of the northern Tien Shan region. In this study, we used remote sensing and field surveys to examine the reasons for the outburst. We found that the lake area changed from $0.021 \mathrm{~km}^{2}$ to $0.002 \mathrm{~km}^{2}$ due to the outburst, in which most of the initial $130,000 \mathrm{~m}^{3}$ of water discharged within four hours. In examining the longer-term behavior of this lake, we found that from 2010 through 2019, it appears in June and disappears in September every year. Its maximum area occurs in late July and early August. With the expansion of the lake basin between 2010 and 2019, the lake also increased greatly in size, particularly so in the three years before the outburst, linked to high summer temperatures and the resulting higher inflow of glacier meltwater, finally leading to the sudden drainage in 2019. Before this outburst, a 2-m high moraine dam retained the lake. Continuously inflowing meltwater and the related increasing pressure by the lake water mass eventually broke the moraine dam. Satellite radar interferometry revealed active displacement fringes in the lake basin and moraine dam due to the melting and subsidence of buried ice. An analysis using digital elevation models from 1964 and 2010 also confirms the surface lowering in the lake basin by up to $8.5 \mathrm{~m}$ and on the moraine dam by $2 \mathrm{~m}$. Such lowering of the proglacial moraine complex destabilized the moraine dam.
\end{abstract}

Keywords: glacial lake; GLOF; lake basin; moraine-dammed lake; moraine complex; Tien Shan

\section{Introduction}

A warming climate continues to degrade glaciers in high mountains, producing numerous new glacial lakes with their associated outbursts every year [1-4]. The Himalayas [5] and the Andes [6] have the most frequent glacial lake outburst floods (GLOFs) that result in severe damage and casualties $[7,8]$. These floods arise when a moraine-dammed lake has a dam failure due to an overtopping wave induced by mass movements, ice falls, ice and snow avalanches or rock-slope failure upslope from the dam [9,10], and/or piping [11] and ice-cored degradation [12] of the dam. In addition, a rising water level and intra-morainal seepages can erode the dam, thus reducing the shear strength of the dam [11]. Such mass-movement triggers of dam failures are common in the Himalayas and Andes $[10,13]$.

Moraine dams consist of weakly-connected sediments that were deposited when a glacier expanded during the Little Ice Age (LIA) [13-15]. In the Andes, the moraine dams that failed were composed of non-cohesive coarse material (boulders and blocks), glaciofluvial deposits, bedrock and ice-cored 
deposits [16]. In the Himalayas, the stability of moraine dams has also been investigated [17-19]. In general, the possibility of dam failure mainly depends on the geometry, material properties, stability and internal structure $[15,20,21]$.

In the northern Tien Shan, most glacial lakes that could cause an outburst flood are small, short-lived and seasonally varying. In some cases, an outburst may depend on the closure of an ice tunnel inside a moraine complex [22-25]. These factors make it difficult to assess their susceptibility to outbursts. Although moraine-dam failures are not the most common cause of outburst floods here, they do occur. Examples include debris flows from such failures in the Kungoy Range in Kyrgyzstan [26] and in the Ili Range in Kazakhstan [27]. Such dam failures here tend to be caused by destabilization of the structure of the moraine dam due to melting of buried ice on the moraine complex [26-30]. In this situation, an increase in the water volume in the lake and a change of stream channel causes the dam to overflow, thus initiating the breach. In addition, the lake basin expands, allowing the lake volume to increase every year. Such an outburst type of moraine-dam failure differs from many cases of mass-movement triggers in the Himalayas and the Andes. A good example is the outburst flood from the Toguz-Bulak lake of the Tosor River basin, Teskey Range, due to a moraine-dam failure on 8 August 2019.

To help understand and eventually reduce the risks from GLOFs, regional characteristics of their development and outburst should be studied. We examine here the behavior of the Toguz-Bulak lake to find the reason for its outburst on 8 August 2019. The lake dynamics are analyzed using remote sensing, climatic conditions and field data. We also investigate the history of the Toguz-Bulak lake's formation and evolution over the past nine years.

\section{Study Area}

The Toguz-Bulak glacial lake lies in the upstream region of the Toguz-Bulak River, the left tributary of the Tosor River, in the northern part of the Teskey Range of the Issyk-Kul basin (Figure 1a). This lake formed on a moraine complex (debris landform including ice) of the Toguz-Bulak Glacier. In 2019, the Toguz-Bulak Glacier had an area of about $5 \mathrm{~km}^{2}$ and the moraine complex had an area of about $1.5 \mathrm{~km}^{2}$. The rocks of the moraine complex originate from Late Ordovician granitoids [31].
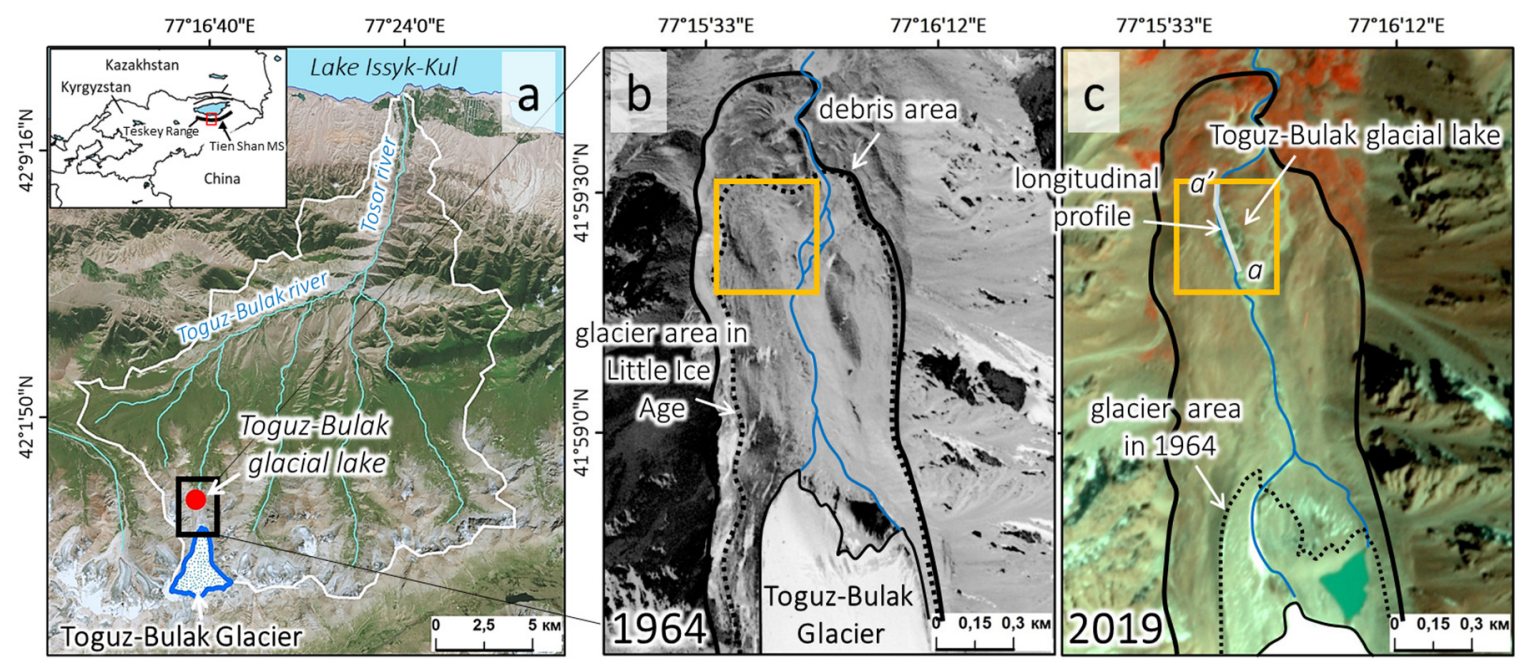

Figure 1. The study area. (a) The Toguz-Bulak river basin (white line) and the glacial lake investigated (red dot). Black rectangle is region of (b) and (c). (b) The moraine complex at the Toguz-Bulak Glacier front revealed from a Corona KH-4A image for 6 October 1964. (c) Same as (b) except from a PlanetScope image for 15 August 2019.

The moraine complex at the Toguz-Bulak Glacier front formed after the retreat of the Toguz-Bulak Glacier, where the glacier terminated at its maximum extent in the Little Ice Age. Now, the glacier 
terminates $175 \mathrm{~m}$ higher in elevation than its lowest Little Ice Age position. Corona KH-4A (Figure 1b) and PlanetScope (Figure 1c) images reveal a horizontal retreat of the Toguz-Bulak Glacier terminus by $680 \mathrm{~m}$ between 1964 and 2019. The elevation of the glacier tongue has also increased, to $3752 \mathrm{~m}$ a.s.l. in 2019, an increase of $72 \mathrm{~m}$ since 1964. These changes are consistent with those in nearby glaciers, which.have lost $8 \%$ of their area during the period 1971-2002 [32].

The period 1964-2019 also shows changes to the stream channel from the lake (Figure 1b,c). In 1964, the stream channel was small. However, over time, stream water widened the main channel, with more meltwater flowing through it. For example, glacial runoff flowed through the left side of the lake-basin in 1964. In 2019, the glacial runoff began flowing directly to the north of the glacier, through the lake basin and the lake dam.

Data obtained from the Tien Shan meteorological station $(3614 \mathrm{~m}, 45 \mathrm{~km}$ ESE of the lake; small-scale map of Figure 1a) show that the average summer temperature increased by almost $0.5{ }^{\circ} \mathrm{C}$ between 1964 and 2019, while the area of the Toguz-Bulak Glacier decreased by $0.56 \mathrm{~km}^{2}$. Over the period 1964-2019, the average precipitation at the same station was $299.7 \mathrm{~mm}$ per year.

\section{Methods}

\subsection{Remote Sensing and Meteorological Data}

For the remote sensing analysis, we used satellite data from Landsat5/TM (2010-2011), Landsat7/Enhanced Thematic Mapper Plus (ETM+, SLC-off, 2010-2015), Landsat8/Operational Land Imager (OLI, 2013-2019), Sentinel-2 (MSI, 2016-2019) and PlanetScope (2018-2019) (Table 1). As a result, the lake characteristics, including seasonal area, were analyzed from June to September for each year 2010-2019. We also examined the changes in the Toguz-Bulak Glacier area during 1964-2019 based on Corona KH-4A (6 October 1964), ALOS/PRISM (2010), Landsat8/OLI (2013), Google Earth-Pro (2013), Sentinel-2/MSI (2017) and PlanetScope (2019) satellite data (Table 1). The glacier outlines were extracted manually following Kääb [32-34]. The lake outlines were delineated manually within the ArcGIS 10.5 software.

Table 1. List of satellite images used for the study.

\begin{tabular}{|c|c|c|c|c|c|}
\hline Satellite & Date & Resolution (m) & Satellite & Date & Resolution (m) \\
\hline Corona KH-4A & 6.10 .1964 & 2.7 & Sentinel-2 & 9.8 .2016 & 10 \\
\hline Landsat-5 TM & 11.6 .2010 & 30 & Sentinel-2 & 18.9 .2016 & 10 \\
\hline Landsat-5 TM & 13.7.2010 & 30 & Sentinel-2 & 8.10 .2016 & 10 \\
\hline Landsat-5 TM & 16.7.2011 & 30 & ALOS-2 & 30.10 .2016 & $9.1 \mathrm{~m} \times 5.3 \mathrm{~m}$ \\
\hline ALOS/PRISM & 10.8 .2010 & 2.5 & Google Earth-Pro & 8.6.2017 & 0.5 \\
\hline ALOS/PRISM DSM & 10.8.2010 & 2.5 & ALOS-2 & 11.6.2017 & $9.1 \mathrm{~m} \times 5.3 \mathrm{~m}$ \\
\hline $\begin{array}{c}\text { Landsat-7 } \\
\text { ETM+/SLC-off }\end{array}$ & 13.8.2010 & 30 & Sentinel-2 & 12.6.2017 & 10 \\
\hline $\begin{array}{l}\text { Landsat-7 } \\
\text { ETM+/SLC-off }\end{array}$ & 22.8.2010 & 30 & Landsat-8/OLI & 30.6 .2017 & 15 (pan) \\
\hline $\begin{array}{l}\text { Landsat-7 } \\
\text { ETM+/SLC-off }\end{array}$ & 6.6 .2011 & 30 & Sentinel-2 & 7.7.2017 & 10 \\
\hline $\begin{array}{c}\text { Landsat-7 } \\
\text { ETM+/SLC-off }\end{array}$ & 24.7.2011 & 30 & Sentinel-2 & 22.7.2017 & 10 \\
\hline $\begin{array}{l}\text { Landsat-7 } \\
\text { ETM+/SLC-off }\end{array}$ & 26.8 .2011 & 30 & Sentinel-2 & 27.7.2017 & 10 \\
\hline $\begin{array}{l}\text { Landsat-7 } \\
\text { ETM+/SLC-off }\end{array}$ & 8.6.2012 & 30 & Sentinel-2 & 9.8.2017 & 10 \\
\hline $\begin{array}{l}\text { Landsat-7 } \\
\text { ETM+/SLC-off }\end{array}$ & 10.7.2012 & 30 & Sentinel-2 & 31.8.2017 & 10 \\
\hline $\begin{array}{l}\text { Landsat-7 } \\
\text { ETM+/SLC-off }\end{array}$ & 11.8.2012 & 30 & Landsat-8/OLI & 2.9.2017 & 15 (pan) \\
\hline
\end{tabular}


Table 1. Cont.

\begin{tabular}{|c|c|c|c|c|c|}
\hline Satellite & Date & Resolution (m) & Satellite & Date & Resolution (m) \\
\hline $\begin{array}{c}\text { Landsat-7 } \\
\text { ETM+/SLC-off }\end{array}$ & 27.8.2012 & 30 & ALOS-2 & 17.9.2017 & $9.1 \mathrm{~m} \times 5.3 \mathrm{~m}$ \\
\hline $\begin{array}{l}\text { Landsat-7 } \\
\text { ETM+/SLC-off }\end{array}$ & 28.9.2012 & 30 & Sentinel-2 & 20.9.2017 & 10 \\
\hline Landsat-8/OLI & 19.6.2013 & 15 (pan) & Sentinel-2 & 10.10 .2017 & 10 \\
\hline Landsat-8/OLI & 5.7 .2013 & 15 (pan) & Sentinel-2 & 10.6.2018 & 10 \\
\hline $\begin{array}{l}\text { Landsat-7 } \\
\text { ETM+/SLC-off }\end{array}$ & 29.7.2013 & 30 & Sentinel-2 & 27.6 .2018 & 10 \\
\hline Landsat-8/OLI & 6.8 .2013 & 15 (pan) & Sentinel-2 & 25.7.2018 & 10 \\
\hline Landsat-8/OLI & 7.9.2013 & 15 (pan) & Sentinel-2 & 16.8 .2018 & 10 \\
\hline Google Earth-Pro & 11.9 .2013 & 0.5 & Sentinel-2 & 5.9 .2018 & 10 \\
\hline $\begin{array}{l}\text { Landsat-7 } \\
\text { ETM+/SLC-off }\end{array}$ & 14.6 .2014 & 30 & Sentinel-2 & 13.9.2018 & 10 \\
\hline $\begin{array}{l}\text { Landsat-7 } \\
\text { ETM+/SLC-off }\end{array}$ & 16.7.2014 & 15 (pan) & Sentinel-2 & 5.7.2019 & 10 \\
\hline Landsat-8/OLI & 25.8 .2014 & 15 (pan) & Sentinel-2 & 10.7.2019 & 10 \\
\hline Landsat-8/OLI & 10.9 .2014 & 15 (pan) & Sentinel-2 & 12.7 .2019 & 10 \\
\hline $\begin{array}{c}\text { Landsat-7 } \\
\text { ETM+/SLC-off }\end{array}$ & 18.9.2014 & 15 (pan) & Sentinel-2 & 15.7.2019 & 10 \\
\hline Landsat-8/OLI & 18.9.2014 & 15 (pan) & Sentinel-2 & 27.7.2019 & 10 \\
\hline $\begin{array}{c}\text { Landsat-7 } \\
\text { ETM+/SLC-off }\end{array}$ & 17.6.2015 & 15 (pan) & Sentinel-2 & 30.7.2019 & 10 \\
\hline Landsat-8/OLI & 11.7.2015 & 15 (pan) & Sentinel-2 & 1.8.2019 & 10 \\
\hline Landsat-8/OLI & 12.8 .2015 & 15 (pan) & Sentinel-2 & 6.8.2019 & 10 \\
\hline $\begin{array}{l}\text { Landsat-7 } \\
\text { ETM+/SLC-off }\end{array}$ & 20.8.2015 & 15 (pan) & Landsat-8/OLI & 7.8.2019 & 15 (pan) \\
\hline Landsat-8/OLI & 29.9.2015 & 15 (pan) & Planet Scope & 8.8.2019 & 3 \\
\hline ALOS-2 & 4.10 .2015 & $9.1 \mathrm{~m} \times 5.3 \mathrm{~m}$ & Sentinel-2 & 11.8.2019 & 10 \\
\hline Landsat-8/OLI & 11.6 .2016 & 15 (pan) & Planet Scope & 30.8 .2019 & 3 \\
\hline Sentinel-2 & 30.6 .2016 & 10 & Sentinel-2 & 3.9.2019 & 10 \\
\hline ALOS-2 & 24.7.2016 & $9.1 \mathrm{~m} \times 5.3 \mathrm{~m}$ & Google Earth-Pro & 1.11 .2019 & 0.5 \\
\hline
\end{tabular}

On 8 August 2019, we learned about the outburst incident from local staff at the Ministry of Emergency Situations of the Kyrgyz Republic (MES KR). The day after the outburst, our team ran a field survey of the lake. The area and bottom of the lake basin after the outburst were investigated using a GPS (Trimble GeoExplorer 6000). Digital elevation model (DEM) data created from GPS data were then used to determine the lake basin volume before and after the outburst, which we assumed to be the volumes of the glacial lake and used to estimate the water discharge. The lake basin area and its volume for 2010 were assessed based on the method used by Narama et al. $[23,35]$ and others [36,37] using a digital surface model (DSM) from data of the Advanced Land Observing Satellite/Panchromatic Remote-sensing Instrument for Stereo Mapping (ALOS/PRISM) [38,39]. We also used the High Mountain Asia 8-meter DEM on 16 July 2017 to calculate basin volume in 2017.

Using the lake volume data for 2019 and an empirical formula reported earlier [40-42], we estimated the outburst's peak discharge. The empirical formula of Popov [40] is based on the outbursts in the Ili Range, Kazakhstan, whereas those in [41] and [42] are based on outbursts in the European Alps. Their estimates were all in close agreement, but we report here just those using Popov's formula. We also interviewed local residents and local staff at the Ministry of Emergency Situations of the Kyrgyz Republic to obtain information about the outburst event.

For the meteorological data, we used average summer temperature (June-October) data from the Tien Shan meteorological station during 2010-2019 (Figure 1a). 


\subsection{Geomorphological Conditions of the Toguz-Bulak Glacial Lake}

To clarify how the geomorphological conditions might have influenced the lake evolution, we examined the surface features of the moraine complex at the Toguz-Bulak Glacier using the ortho-rectified satellite images from Corona KH-4A data taken on 6 October 1964 and from PlanetScope taken on 15 August 2019. The image from Corona KH-4A was created using ground control points (GCPs) extracted from ALOS/PRISM DSM data on 10 November 2010 with a 2.5-m resolution, and then a DSM was generated from the Corona data using the software Metashape (Agisoft, St. Petersburg, Russia). For GCPs, we used valley bottoms and large, stable rocks. The height errors of the PRISM

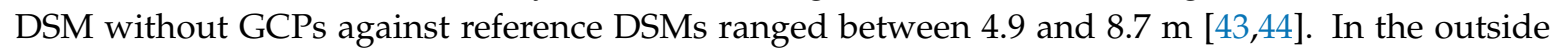
(stable area) of the moraine complex, the DSM differences between the Corona KH-4A DSM (1964) and ALOS/PRISM DSM (2010) averaged $-0.57 \pm 1.78 \mathrm{~m}$. The average difference between the Corona DSM and the High Mountain Asia 8-meter DEM is $-0.75 \pm 1.94 \mathrm{~m}$, whereas that between the ALOS/PRISM and High Mountain Asian DSMs is $-0.37 \pm 1.66 \mathrm{~m}$. These uncertainties are significantly less than the lake-level variations that could vary up to $8.5 \mathrm{~m}$.

Concerning lake-area uncertainty, we compared the lake areas taken manually on 6 August 2019 (Sentinel-2) and 7 August 2019 (Landsat8/OLI) with the maximum lake area on 8 August that was measured by GPS after the outburst. The resulting differences in lake areas of $0.019 \mathrm{~km}^{2}$ (Sentinel-2), $0.018 \mathrm{~km}^{2}$ (Landsat8/OLI), and $0.021 \mathrm{~km}^{2}$ (GPS) are considered small because their effect on the volume uncertainty is less than that from uncertainty in DSM. Thus, we consider the uncertainty in volume to be small.

To understand how the Toguz-Bulak lake basin changed over 2010, 2013, 2017 and 2019 and how the changes influenced the lake, we analyzed the evolution of the lake basin using ALOS/PRISM (2010) and Google Earth-Pro (2013, 2017 and 2019) satellite data. The outlines of the lake basin were delineated manually as polygon data using ArcGIS 10.5. Then, we calculated the volume of the lake basin based on the ALOS/PRISM DSM data for 2010. For 2017, we used the High Mountain Asia 8-m DEM, and for 2019, the DEM from GPS data. The GPS data from 2019 and DSMs from the Corona KH-4A (1964) and ALOS (2010) satellites were also examined to obtain information about vertical surface changes at the lake basin and to compute a profile.

We also studied the potential role of vertical subsidence of the moraine complex around the lake-basin. For that purpose, we applied a differential interferometric SAR (DInSAR) analysis using radar image pairs of phased array type L-band synthetic aperture radar-2 (PALSAR-2) data from the ALOS-2 satellite [45-47]. The GAMMA SAR software was used for processing [48-50]. In total, we used 6 image pairs from 4 October 2015 to 24 July 2016, from 24 July 2016 to 30 October 2016, and from 11 June 2017 to 17 September 2017. Using a series of repeated DInSAR interferograms at intervals of 1-2 years or a few summer months enabled to map short- or long-term vertical displacements, respectively [46,51]. Vertical subsidence and horizontal motion due to ground ice melting were detected based on displacement fringes $[25,33,46,48]$.

\section{Results}

\subsection{Outburst of Toguz-Bulak Glacial Lake on 8 August 2019}

During each summer of 2010-2019, the lake area gradually increased. The area increased until the lake began to overflow through a spillway channel. The maximum area varied significantly from year to year. In the summer of 2019, the lake area increased as in other years but became significantly larger than that in the previous years.On about 5 July 2019, the glacial lake appeared in the lake basin (Figure 2a) and steadily increased in size (Figure 3). Within a month (Figure 2b), the lake area increased 36-fold with a daily expansion rate of $574 \mathrm{~m}^{2} /$ day. On 7 August, its surface height reached the maximum level of the lake basin (Figure 2c). The next day a slight further expansion induced overtopping, leading to the outburst flood (Figure 2d). From Figure 3, a high rate of lake-area expansion can be seen between 5 July and 8 August 2019. During this time, the lake area expanded at a rate of 
$660 \mathrm{~m}^{2}$ per day. Then, on 8 August, the moraine dam of the Toguz-Bulak glacial lake breached and caused an outburst flood in the upper left tributary of the Tosor River (Figure 2d).

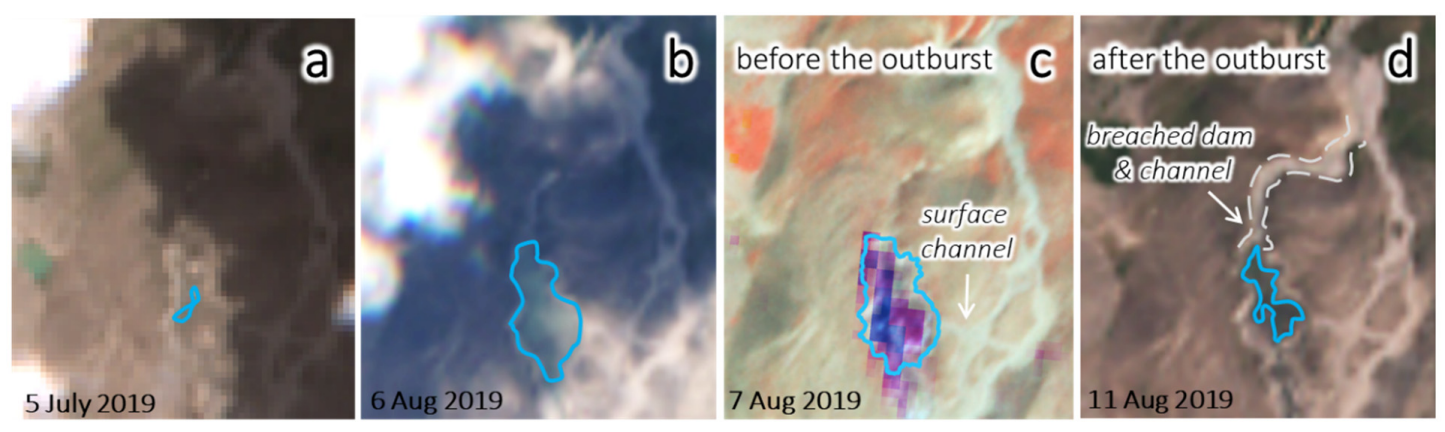

Figure 2. Perimeter of the Toguz-Bulak glacial lake during July-August 2019. (a,b) Image data from the Sentinel-2 satellite taken on (a) 5 July and (b) 6 August. (c) Lake margin data from the Landsat8/OLI satellite taken on 7 August. (d) Image data from the Sentinel-2 satellite taken on 11 August. Blue lines are outline of the lake.

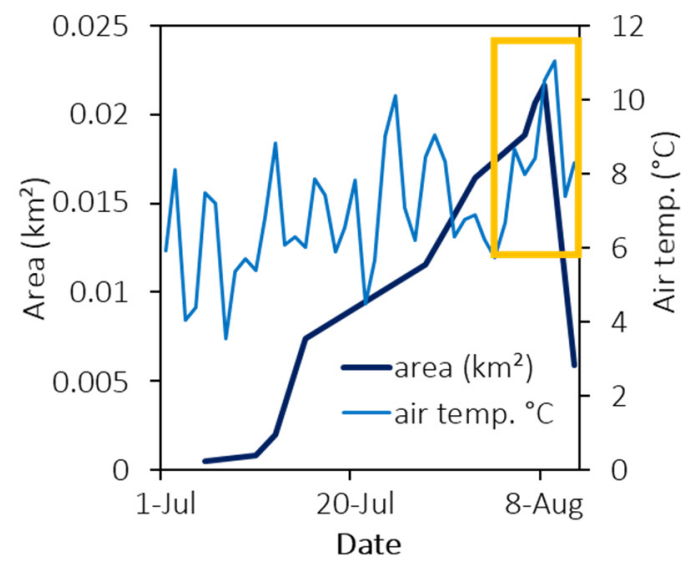

Figure 3. Lake area and summer daily average air temperatures in 2019 (Tien Shan meteorological station (MS)).

The field survey showed that the lake area decreased from $0.021 \mathrm{~km}^{2}$ before the outburst to $0.002 \mathrm{~km}^{2}$ after the outburst, while the water level in the lake dropped by $6 \mathrm{~m}$. The resulting calculation of the water volume loss is about $130,000 \mathrm{~m}^{3}$.

People living downstream reported that the outburst event from the lake started at around 15:00 o'clock, local time. About $30 \mathrm{~min}$ later, a large wave came through and then the flood slowly decreased, ending at about 19:00 o'clock. Our calculation, based on an estimated volume of the lake basin (following the empirical formula in [40]), gives a peak discharge rate during the four-hour long outburst of $183 \mathrm{~m}^{3} / \mathrm{s}$. This peak discharge is close to that from other moraine-dam failures [41,42].

The outburst incident coincides with an increase in average air temperature in August (orange rectangle, Figure 3). In addition, the air temperature measured at 14:00-15:00 o'clock on 8 August exceeded $30^{\circ} \mathrm{C}$, which must have induced a strong temporary increase in glacier meltwater coming into the lake basin. The lake emptied, to a large extent, within four hours, with an average discharge rate of $32,500 \mathrm{~m}^{3}$ per hour.

Images from the field survey show the trace of the earlier lake level. Before the outburst, water from the lake overflowed through a well-developed V-shaped surface channel to the southeast of the lake (Figure 4a). Hence, the dam-breach at the northern lake shore (Figure $4 b$ ) changed the course of water runoff (Figure 1b,c). The outburst flood eroded the valley flanks, forming deep ravines to a depth of $3 \mathrm{~m}$ (Figure 4c). The water and debris mixture flowed into the Tosor River, depositing on the riverbed 
(Figure 4d) and reaching Lake Issyk-Kul after $30 \mathrm{~km}$. The flood damaged two bridges, as well as destroying pastures and parts of the road in Bokonbaev Village.

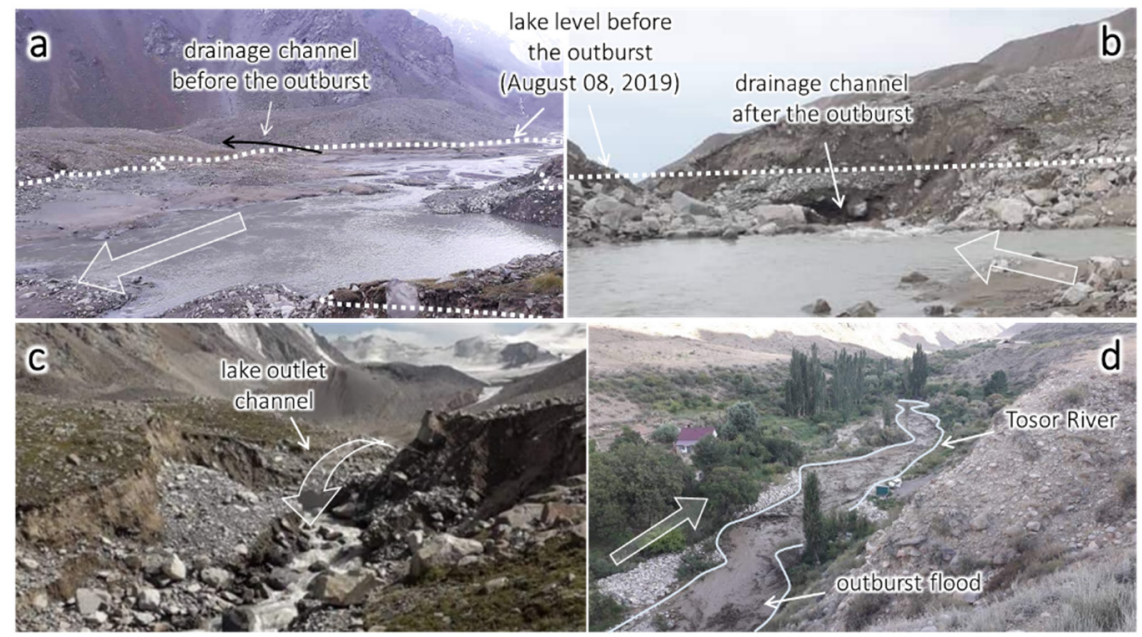

Figure 4. The Toguz-Bulak glacial lake outburst flood. All photos taken on 9 August 2019. (a) Lake condition after the outburst. (b) Drainage channel through the dam. (c) Lake outlet from below and eroded stream banks. (d) Flooded area along the Tosor River. Large white arrows show the flow direction.

\subsection{Toguz-Bulak Glacial Lake Area Variability during 2010-2019}

During 2010-2019, the lake appeared every year in June with a seasonally increasing air temperature and disappeared in September with a decreasing air temperature. The satellite image analysis in Figure 5 shows relatively small peak lake areas over the summers of 2010-2012. The peak lake area increased significantly more in 2013-2016, and the largest peak lake areas occurred in 2017, 2018 and 2019. Thus, we divided the lake area variation into two phases: (1) a phase of rather small seasonal variations, from 2010 to 2016 (red shading, Figure 5), and (2) a phase of large variations, from 2017 to 2019 (blue shading).

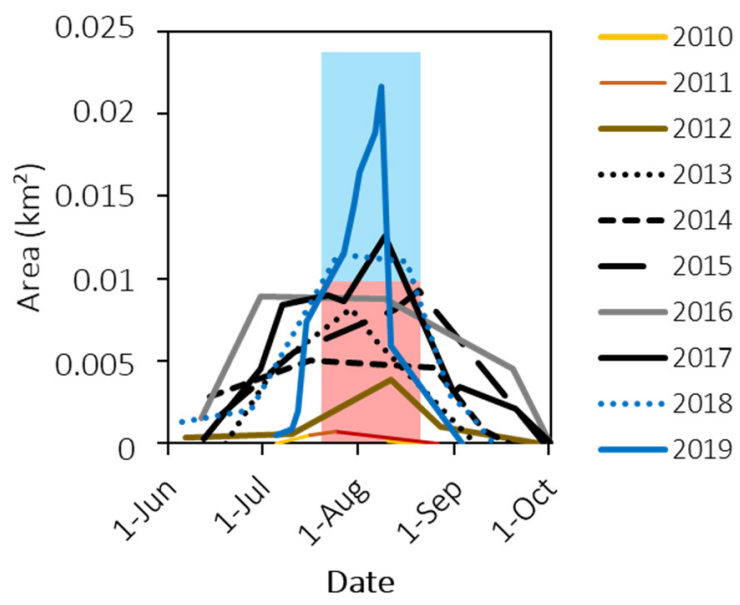

Figure 5. Toguz-Bulak lake area during 2010-2019. Red shading shows small seasonal variations (2010-2016); blue shading shows large variations (2017-2019).

\subsection{Meteorological Factors Behind the Increase in Lake Area}

To assess a relationship between the lake dynamics and summer air temperature, we analyzed the average summer temperature for June-July in 2010, 2013, 2017 and 2019. An increase in summer temperature by $0.2^{\circ} \mathrm{C}$ (light blue line, Figure 6a) over the last 9 years correlates with the loss of $0.17 \mathrm{~km}^{2}$ 
in area of the Toguz-Bulak Glacier (dark blue line). In the period 2010-2013, the glacier area decreased by $0.07 \mathrm{~km}^{2}$, over 2013-2017, the area lost was $0.08 \mathrm{~km}^{2}$, and during 2017-2019, the loss was $0.02 \mathrm{~km}^{2}$. Averaging over the 9 years, the Toguz-Bulak Glacier area decreased $0.019 \mathrm{~km}^{2} /$ year.
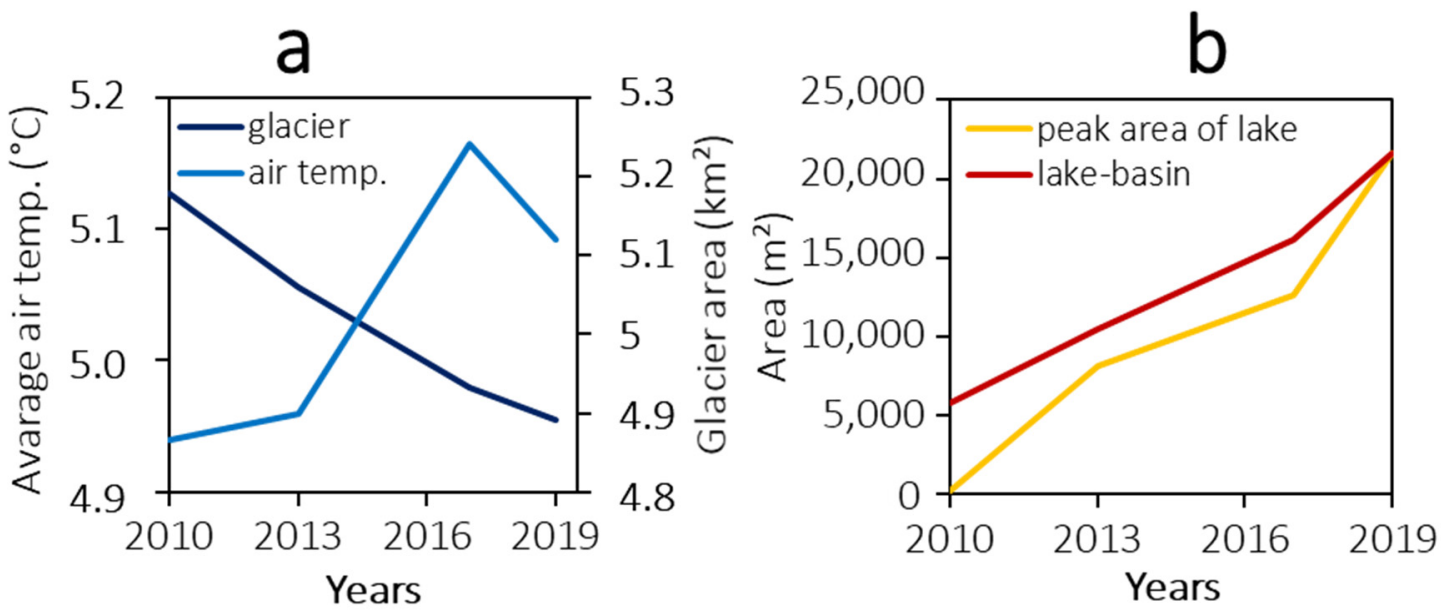

Figure 6. Average air temperatures (June-July) and areas of the Toguz-Bulak glacier, lake and lake basin. (a) Air temperature and glacier area. (b) Lake and lake basin areas. Air temperature data from MS Tien Shan.

The glacier area reduction must have been accompanied by a corresponding ice volume loss, causing an increase in glacial runoff volume. For instance, we found a similar increase in glacial runoff to the Chong-Kyzylsuu river in the Teskey Range that was a prerequisite for the rapid rise (and later drainage) in the water level of the $\mathrm{w}$-Zyndan glacial lake [22]. In the present case, an increase in the glacier runoff would have expanded the Toguz-Bulak lake basin every year (red line, Figure 6b). Incoming glacial runoff controlled the behavior of the Toguz-Bulak lake, that is, the lake area varied with the incoming volume of glacial runoff (orange line, Figure 6b). As the peak lake area (Figure 6b) increases with the increasing loss of glacial area (Figure 6a), we suggest that the peak lake area primarily depends on the incoming rate of glacial runoff. The large glacial runoff caused particularly large peak lake areas in 2017-2019. These larger peak lake areas are likely related to the higher air temperature in June-July 2017-2019 compared to the years 2010-2016. Furthermore, more rapid melting of snow and ice under the higher air temperatures in June-July 2017-2019 would lead to the more rapid rise in the lake level, shown in Figure 5. We rule out precipitation as the cause of the higher lake levels because, according to the Tien Shan MS, (1) the total summer precipitation decreased through the years 2017-2019 and (2) the precipitation amount during June-July was negligible (for 2019, just $85.5 \mathrm{~mm}$ ).

\subsection{Geomorphological Processes Influencing the Development of the Toguz-Bulak Glacial Lake}

We now consider the formation and size of the lake basin. In 1964, the lake basin had not yet formed. At this time, as shown in Figure 7a, glacier meltwater flowed through the upper edge of a sector "A" (Figure 1b). However, an increase in glacial runoff (blue arrows in Figure 7) on the moraine complex contributed to the formation of the lake basin. In 2010, water stagnated in the region just left of sector " $\mathrm{A}$ " and had begun expanding its area by mechanical erosion, and likely also by thermal erosion. Until this time, ravines were formed to a depth of about $1 \mathrm{~m}$. Then, during each year between 2010 and 2017, glacier meltwater flowed into the lake basin and out again through the upper margin of sector " $\mathrm{A}$ ". The stagnant water in the lake basin helped to erode the basin bottom and shoreline. In particular, ALOS/PRISM satellite data from 2010 show a small lake basin of 0.0058 $\mathrm{km}^{2}$ in area (Figure 7b). Later, by 2013, the basin size had doubled in area (Figure 7c). By 2017, the lake basin area had grown to $0.016 \mathrm{~km}^{2}$ (Figure $7 \mathrm{~d}$ ), and by 2019, to $0.021 \mathrm{~km}^{2}$ (Figure 7e). Thus, over 2010-2019, the lake basin area increased over three-fold, eventually reaching the moraine dam at 
the north side of the lake basin, a distance of $100 \mathrm{~m}$ (Figure 7f). When the moraine dam (ridge) failed in 2019, the meltwater flowed through the northern dam instead of the eastern shore (Figure 1c).

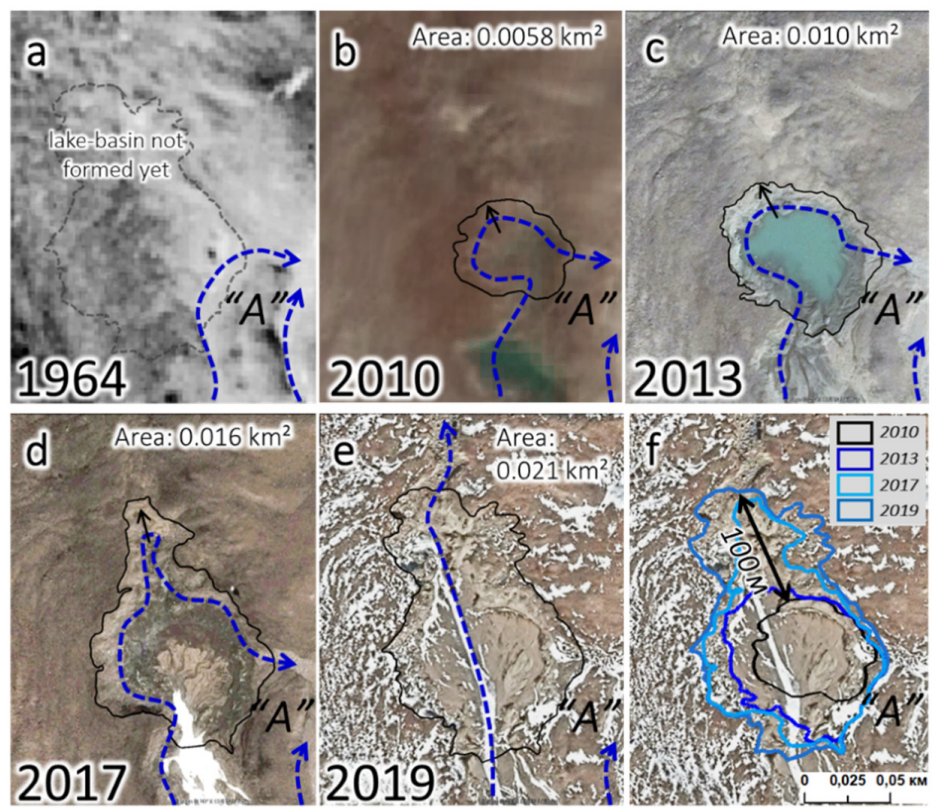

Figure 7. The Toguz-Bulak lake basin, 1964-2019. (a) Image from Corona KH-4A on 6 October 1964. (b) Advanced Land Observing Satellite/Panchromatic Remote-sensing Instrument for Stereo Mapping (ALOS/PRISM) image in 2010. (c-e) Images from Google Earth (World View), 2013-2019. (f) Boundaries of the lake basin during 2010-2019 (background image from Google Earth (World View), 2019).

The dashed blue lines show the direction of meltwater flow.

With the increase in lake basin area, the lake basin volume also increased. For example, in 2010, the lake basin volume was $63,000 \mathrm{~m}^{3}$. Over 2017-2019, the volume of the lake basin had increased by $44,000 \mathrm{~m}^{3}$, then totalling about $130,000 \mathrm{~m}^{3}$. Thus, over the period $2010-2019$, the lake basin volume had risen by almost 1.7 times.

In addition, the lake basin region lowered during 1964-2010. Figure 8a shows how the elevation changed over the entire basin region. Around the basin's dam area, the surface had lowered by 1.0 to $2.0 \mathrm{~m}$, whereas along a slice through the center of the basin, the surface shows a lowering by up to $8.5 \mathrm{~m}$ (Figure $8 \mathrm{~b}$ ). Such surface lowering of a moraine complex is consistent with that found nearby at the Jeruy Glacier front in the Teskey Range [25].
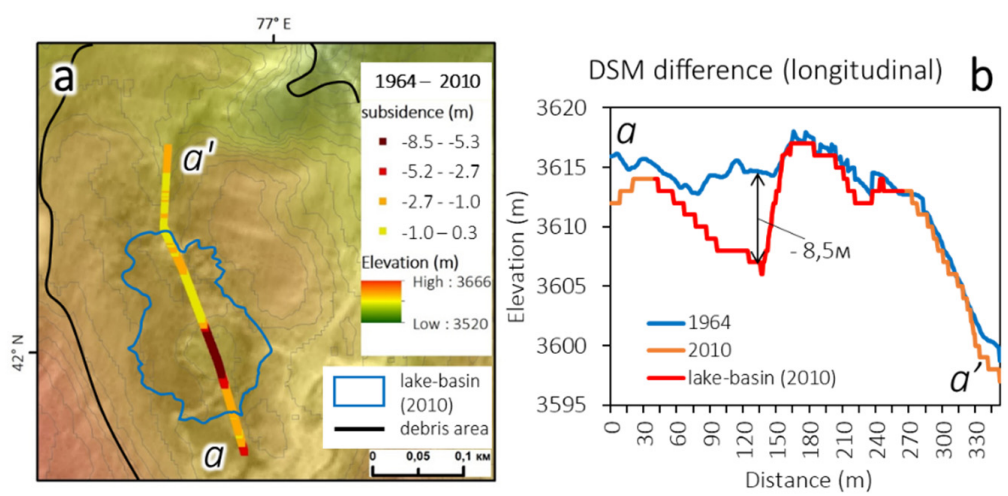

Figure 8. Surface elevations at the lake basin and moraine dam area in 1964 and 2010. (a) Digital surface model (DSM) differences on the surface in the map and (b) longitudinal profile of the two DSMs along a-a'. Profile location showed in Figure 1C. Data based on DSMs generated from Corona KH-4A, taken on 6 October 1964, and from ALOS, taken on 10 November 2010. 
Using the GPS data from 2019, we examined more recent profile changes along the lake basin and moraine dam. Over the last nine years, a significant height loss or subsidence occurred in the middle part and the dam area of the lake. During this time, the bottom of the lake lowered by $1 \mathrm{~m}$. However, changes in lake bottom are quite different in other areas of the lake-basin. In particular, Figure 9a shows that the surface elevation in the basin center lowered by $4 \mathrm{~m}$ and in the dam area by $2 \mathrm{~m}$ (a sudden drop by $2 \mathrm{~m}$ after drainage). Thus, since 2010, the lake basin's surface has continued to lower and its size has increased.

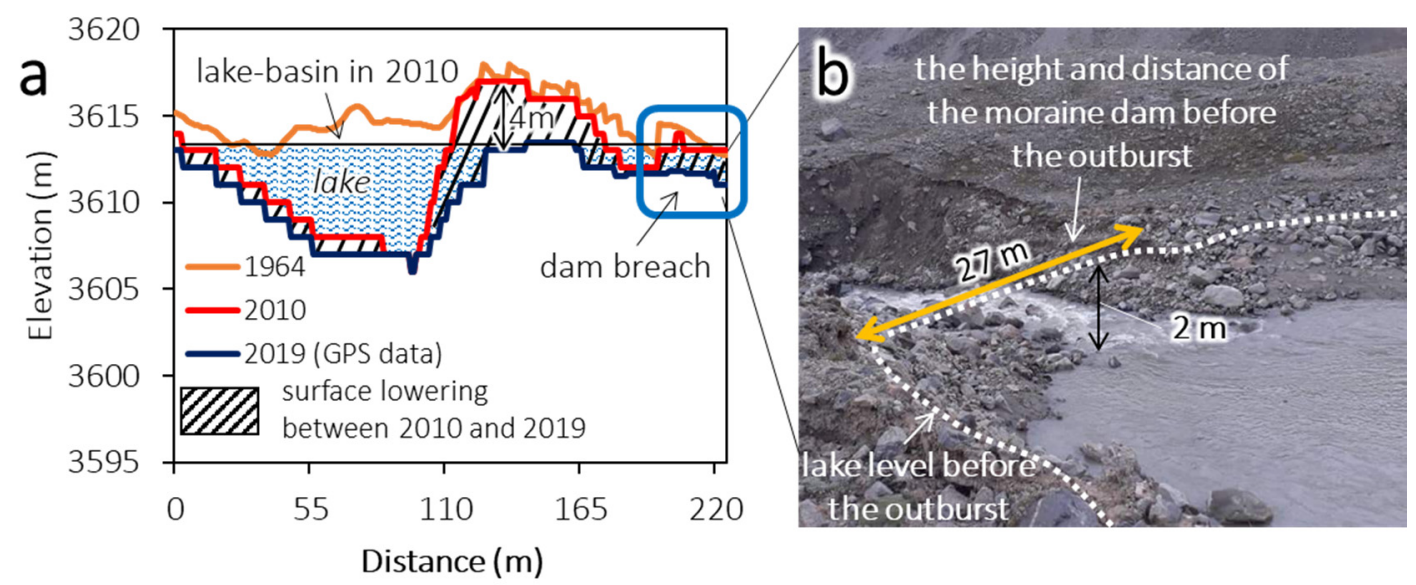

Figure 9. Basin profiles and moraine dam region. (a) Longitudinal profiles along the lake basin and moraine dam before and after outburst (along a-a' in Figure 8). The blue square shows elevation changes at the dam. The profiles were compiled based on ALOS DSM (2010) and GPS data (2019). Background orange profile from Corona KH-4A/DSM for 1964. (b) The breached dam region the day after the outburst (9 August 2019).

Before the outburst event, a 2-m high, 27-m wide and 1.5-2.0-m thick stretch of the moraine dam held back the glacial lake (Figure 9b). The moraine dam resisted for two days, on 6 th and 7 th August, and then failed (Figure 2b,c).

\subsection{Surface Changes on the Moraine Complex}

To better understand the changes around the lake basin, we used DInSAR interferograms to measure the surface motion on the moraine complex. We analyzed three periods: between 4 October 2015 and 24 July 2016, between 24 July 2016 and 30 October 2016 and between 11 June 2017 and 17 September 2017. Results in Figure 10 show that significant movement occurred on the surface of the moraine complex during all three years, with sectors " 1 ", " 2 " and " 3 " being the most active areas. The largest surface displacements occurred in the lake basin area, marked as sector " 3 ". Here, the line-of-sight deformation rate exceeds $11.9 \mathrm{~cm}$ per year.

This sustained surface motion in all three sectors suggests melting and movement of ground ice and related subsidence $[25,33,46]$. This indicates that, as with other moraine complexes in the area $[23,25]$, the moraine complex contains ground ice. This ground ice degrades, leading to development of the lake and its dam failure. According to the mean annual ground surface temperature (MAGST), mean annual air temperature (MAAT) [25] and a global 1-km resolution permafrost model [52], the study site is very likely within the regional permafrost limit. Thus, either the debris cover on top of the ground ice within the moraine complex is relatively thin or the ice core of the moraine complex is not in equilibrium. 


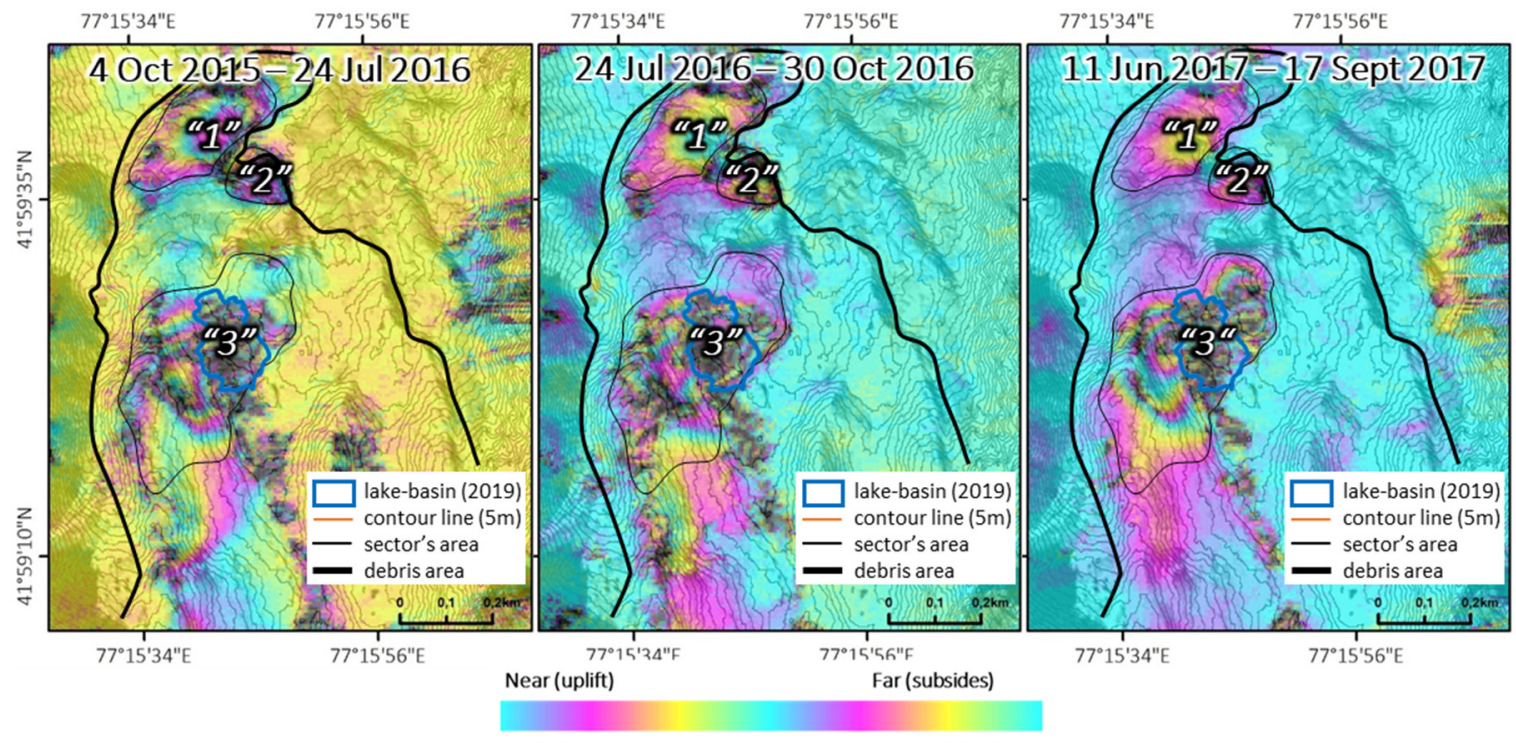

$-11.8 \mathrm{~cm} \quad$ Los deformation rate $(\mathrm{cm})+11.8 \mathrm{~cm}$

Figure 10. Surface displacement maps, 2015-2017. From differential interferometric SAR (DInSAR) data from ALOS-2/phased array type L-band synthetic aperture radar-2 (PALSAR-2).

\section{Discussion}

\subsection{Lake Development and Outburst on a Moraine Complex}

The lake development and failure mechanism here differ from the ice avalanches or intra-morainal seepages that lead to similar failures in the Himalayas and the Andes [11,13,15,53,54]. In the eastern Himalayas [55], the formation of large lake basins is mainly due to glacier recession on debris-covered glaciers. Melting of ground ice inside the moraine is promoted [12,20] because the large-scale moraine-dammed lakes are located below the permafrost zone $[25,56]$. However, in those areas, ice melting in the moraine is not the main reason for moraine-dam failure.

The study region here contains many other moraine complexes with ice. Using DInSAR analysis, Daiyrov et al. [25] found evidence for many moraine complexes with ground ice at glacier fronts in the Teskey Range. Further evidence for ground ice came from the analysis of two DSMs generated from Corona (1964) and ALOS/PRISM (2010) data that showed surface subsidence [25]. Many lake basins (depressions) here can be formed by either glacier recession or by surface subsidence due to melting on the moraine complex in the permafrost zone above $3000-3200 \mathrm{~m}$ a.s.l. $[22,23,25,30,56]$. The Toguz-Bulak glacial lake is a moraine-dammed lake that developed in a depression on an ice-cored moraine complex. The lake appears in spring-early summer and disappears in autumn, due to the discharge of glacier runoff. Each year, the lake basin area and volume increased due to degradation and back wasting of ground ice and erosion by stream water and later reached the edge of the moraine complex.

Another cause is an increase in glacier runoff occurring with an increase in summer temperature. We found a large area increase in the years 2017-2019, partly due to greater glacial runoff, induced by particularly high summer temperatures. Hence, in addition to the role of glacier recession, in this region, the basins can then grow via thermal erosion [57] and the flow of glacier meltwater (this study).

In addition, the melting of ground ice decreases dam stability, thus increasing the probability of a dam failure $[12,15,20,58]$. For example, debris flow due to moraine-dam failures has occurred in the Kungoy Range in Kyrgyzstan [26] and the Ili Range in Kazakhstan [27]. These failures were caused by destabilization of the moraine-dam structure due to surface subsidence and seepages of the lake through ground channels that opened up when ice melted [26]. Through surface changes on the moraine complex, triggers of the outburst include (1) piping under a step hydraulic head with backward erosion from the air side of the dam, (2) a mechanical breach under high water pressure, and combinations of these factors, (3) overtopping and backward erosion or incision into the dam and 
(4) melting of an ice core and subsequent dam failure. In the present case, the main factors are likely

(3) and (4). These might also be applied to mountain permafrost regions in Asian mountains.

\subsection{Two Types of Water Storage and Drainage Systems on a Moraine Complex}

The Toguz-Bulak glacial lake is a recurring lake type, similar to the Koltor glacial lake in the Tong River basin [25]. Both glacial lakes have an annual cycle of appearing in spring-early summer and disappearing in autumn. However, only the Toguz-Bulak has a surface drainage channel from the lake. The Koltor lake instead drains through an ice tunnel. In the case of the Toguz-Bulak lake, appearance of the lake depends on the inflow of meltwater, so with increasing amounts of meltwater, the lake basin and lake expanded from year to year. Eventually, more than a decade after it started forming, the lake basin perimeter reached, and then breached, its moraine dam top. In contrast, the Koltor lake basin formed almost a century ago, when the glacier started to retreat, with only slight subsequent changes in basin size. Therefore, despite their apparently similar geomorphological conditions, the water storage and discharge systems of these two lakes differ significantly from each other.

When the Toguz-Bulak lake dam failed, the lake completely drained within hours. The estimated maximum discharge was $183 \mathrm{~m}^{3} / \mathrm{s}$. Such rapid drainage has so far been uncommon in the Teskey Range. Here, all large-scale drainages during the last ten years have been from short-lived lakes via an underground ice channel, producing rates of only $12-27 \mathrm{~m}^{3} / \mathrm{s}[22,23,25]$. The current study also revealed a short-lived lake, but one that drained through a breached moraine dam. The reason behind past drainages was ice-tunnel closure due to ice-debris blockages or due to freezing of stored water inside the tunnel. In those cases, the lake water quickly filled up the lake basin, and then, under high water pressure and thermal erosion, the ice tunnel opened, producing a large drainage $[22,23,25]$. A similar tunnel system is typically well developed at supraglacial lakes [35,59].

Given the large differences in maximum discharge from lakes having these two types of drainage systems, we should determine whether other lakes in the region are of the same type as that of Toguz-Bulak. The work will involve monitoring the surface changes and lake development on moraine complexes. With global warming, both types of outburst may occur in the study region more frequently in the future, particularly near the bottom of the permafrost zone [55], giving such work greater importance.

\section{Conclusions}

We used satellite images and a field survey to study the dynamics and geomorphology of the Toguz-Bulak glacial lake, before and after its outburst that caused flooding on 8 August 2019. Because of the outburst, the lake area decreased from 0.021 to $0.002 \mathrm{~km}^{2}$ in four hours, releasing about $130,000 \mathrm{~m}^{3}$ of water.

Satellite image analyses for the years 2010-2019 revealed that the lake appeared each year in June and vanished in September. The peak lake size would occur in late July to early August. We found a large area increase in the years 2017-2019 and argued that this was mainly due to greater glacial runoff induced by particularly high summer temperatures. In addition, each year, the lake basin area and volume increased due to degradation and back wasting of ground ice and erosion by stream water. Periods of high air temperatures that initiated increases in glacier runoff in 2017-2019 expanded the lake basin area by $0.016 \mathrm{~km}^{2}$ and volume by $44,000 \mathrm{~m}^{3}$, and subsequently, the seasonal variations in lake area increased in amplitude.

We also found that between 1964 and 2010, the lake basin lowered by up to $8.5 \mathrm{~m}$. The bottom of the lake lowered 1 additional meter by 2019. The vertical changes in the lake bottom are significantly different within the lake basin. Using DInSAR analyses between 2015 and 2017, we found active surface motion with line-of-sight displacements of over $11.9 \mathrm{~cm} /$ year around the lake. These surface displacements likely stemmed from subsidence and lateral motion associated with the melting and movement of ground ice. 
The factors identified here as likely causes for the lake outburst might also be important influences on other glacial lakes in the Tien Shan mountains. Therefore, other glacial lakes on moraine complexes should be studied and monitored. However, short-lived lakes having an ice-tunnel drainage are very unpredictable and difficult to monitor from optical satellites. Such cases require high-frequency monitoring based on medium- to high-resolution optical and SAR satellites with short revisit times, such as ALOS-2 and PlanetScope as well as Sentinel-2 and Sentinel-1, preferably in combination.

Currently, more than 400 glacial lakes exist in the northern Tien Shan region [60]. Especially the ones on moraine complexes pose a particularly high risk from outburst floods. It is impossible to investigate all of these glacial lakes on site but the use of remote sensing methods allows their monitoring $[25,60]$. Such an approach can save much time and money.

Author Contributions: Authors M.D. and C.N. conducted the field survey and performed an analysis of field and satellite data. T.T. supported the DInSAR analysis with ALOS-2/PALSAR-2 data. M.D. wrote the paper. A.K. and C.N. checked and improved the manuscript and suggested some discussion points. All authors have read and agreed to the published version of the manuscript.

Funding: This research was funded by the National Scientific Research Program Project of the Central-Asian Institute for Applied Geosciences (CAIAG) of the Kyrgyz Republic (Project-2.2), and the Grant-in-Aid for Scientific Research (B) $19 \mathrm{H} 01372$ of the Ministry of Education, Culture, Sports, Science and Technology (MEXT) of Japan, Japanese Government (MEXT) Scholarships at Graduate School of Science and Technology, Niigata University in 2015-2017. A.K. acknowledges funding by the ESA Glaciers_cci and Permafrost_cci projects (4000109873/14/I-NB, 4000127593/19/I NB, 4000123681/18/I-NB).

Acknowledgments: We would like to thank Moldobekov Bolot, co-director of the CAIAG, and Usubaliev Ryskul, head of the Department of Climate, Water and Natural Resources, for their support of our research. We also would like to express our thanks for the valuable comments of an editor and two reviewers of this paper. Finally, we also would like to thank the staff at MES of Kyrgyzstan and local residents for interviews and support in the field work and every participant involved in this work.

Conflicts of Interest: The authors declare no conflict of interest. The funding sponsors had no role in the design of the study; in the collection, analyses, or interpretation of data; in the writing of the manuscript, and in the decision to publish the results.

\section{References}

1. Carrivick, J.L.; Tweed, F.S. A global assessment of the societal impacts of glacier outburst floods. Glob. Planet. Chang. 2016, 144, 1-16. [CrossRef]

2. Harrison, S.; Kargel, J.S.; Huggel, C.; Reynolds, J.; Shugar, D.H.; Betts, R.A.; Emmer, A.; Glasser, N.; Haritashya, U.K.; Klimeš, J. Climate change and the global pattern of moraine-dammed glacial lake outburst floods. Cryosphere 2017, 12, 1195-1209. [CrossRef]

3. Hock, R.; Rasul, G.; Adler, C.; Cáceres, B.; Gruber, S.; Hirabayashi, Y.; Jackson, M.; Kääb, A.; Kang, S.; Kutuzov, S. High Mountain Areas. In IPCC Special Report on the Ocean and Cryosphere in a Changing Climate (SROCC); Kaser, G., Mukherji, A., Eds.; IPCC: Geneva, Switzerland, 2019.

4. Veh, G.; Korup, O.; Walz, A. Hazard from Himalayan Glacier Lake Outburst Floods. Proc. Natl. Acad. Sci. USA 2020, 117, 907-912. [CrossRef] [PubMed]

5. Bajracharya, S.R.; Shrestha, B.R.; Rajbhandari, L. Glacial lake outburst floods in the Sagarmatha region. Mt. Res. Dev. 2007, 27, 336-344. [CrossRef]

6. Klimeš, J. Geomorphology and natural hazards of the selected glacial valleys, Cordillera Blanca, Peru. AUC Geogr. 2012, 47, 25-31. [CrossRef]

7. Hewitt, K.J. Natural dams and outburst floods of the Karakoram Himalaya. In Hydrological Aspects of Alpine and High Mountain Areas (Proceedings of the Exeter Symposium, July 1982); IAHS Publ. 138; International Association of Hydrological Sciences (IAHS): Great Yarmouth, UK, 1982; pp. 259-269.

8. Reynolds, J.M. High-altitude glacial lake hazard assessment and mitigation: A Himalayan perspective. In Geohazards in Engineering Geology; Maund, J.G., Eddleston, M., Eds.; Engineering Geology Special Publication No. 15; Geological Society: London, UK, 1998; pp. 25-34. [CrossRef]

9. Costa,J.E.; Schuster, R.L. The formation and failure of natural dams. Geol. Soc. Am. Bull. 1988, 100,1054-1068. [CrossRef]

10. Emmer, A.; Cochachin, A. The causes and mechanisms of moraine-dammed lake failures in the Cordillera Blanca, North American Cordillera, and Himalaya. Acta Univ. Carol. Geogr. 2013, 48, 5-15. [CrossRef] 
11. Shreshta, B.B. Glacial Lake Outburst due to Moraine Dam Failure by Seepage and Overtopping with Impact of Climate Change; Annuals of Disaster Prevention Research Institute, Kyoto University: Kyoto, Japan, 2010; Volume 53B.

12. Richardson, S.D.; Reynolds, J.M. An overview of glacial hazards in the Himalayas. Quat. Int. 2000, 65, 31-47. [CrossRef]

13. Neupane, R.; Chen, H.; Cao, C. Review of moraine dam failure mechanism. Geomat. Nat. Hazards Risk 2019, 10, 1948-1966. [CrossRef]

14. Evans, S.G.; Clague, J.J. Recent climatic change and catastrophic geomorphic processes in mountain environments. Geo Nat. Haz. 1994, 10, 107-128. [CrossRef]

15. Clague, J.J.; Evans, S.G. A review of catastrophic drainage of moraine-dammed lakes in British Columbia. Quater Sci. Rev. 2000, 19, 1763-1783. (In English) [CrossRef]

16. Iribarren Anacona, P.; Norton, K.P.; Mackintosh, A. Moraine-dammed lake failures in Patagonia and assessment of outburst susceptibility in the Baker Basin. Nat. Hazards Earth Syst. Sci. 2014, 14, 3243-3259. [CrossRef]

17. Watanabe, T.; Lamsal, D.; Ives, J.D. Evaluating the growth characteristics of a glacial lake and its degree of danger of outburst flooding: Imja Glacier, Khumbu Himal, Nepal. Norsk Geogr. Tidsskr. 2009, 63, 255-267. [CrossRef]

18. Emmer, A.; Vilímek, V. New method for assessing the susceptibility of glacial lakes to the outburst floods in the Cordillera Blanca, Peru. Hydrol. Earth Syst. Sci. 2014, 18, 3461-3479. [CrossRef]

19. Prakash, C.; Nagarajan, R. Outburst susceptibility assessment of moraine-dammed lakes in Western Himalaya using an Analytic Hierarchy Process. Earth Surface Process. Landf. 2017, 42. [CrossRef]

20. Richardson, S.D.; Reynolds, J.M. Degradation of ice-cored moraine dams: Implications for hazard development. In Debris Covered Glaciers; IAHS Punbl.no. 264; International Association of Hydrological Sciences (IAHS): Washington, DC, USA, 2000; pp. 187-197.

21. Worni, R.; Stoffel, M.; Huggel, C.; Volz, C.; Luckman, B. Analysis and dynamic modeling of a moraine failure and glacier lake outburst flood at Ventisquero Negro, Patagonian Andes (Argentina). J. Hydrol. 2012, 444, 134-145. [CrossRef]

22. Narama, C.; Duishonakunov, M.; Kääb, A.; Daiyrov, M.; Abdrakhmatov, K. The 24 July 2008 outburst flood at the western Zyndan glacier lake and recent regional changes in glacier lakes of the TeskeyAla-Too range, Tien Shan, Kyrgyzstan. Nat. Hazards Earth Syst. Sci. 2010, 10, 647-659. [CrossRef]

23. Narama, C.; Daiyrov, M.; Duishonakunov, M.; Tadono, T.; Hayato, S.; Kääb, A.; Ukita, J.; Abdrakhmatov, K. Large drainage from short-lived glacial lakes in the Teskey Range, Tien Shan Mountains, Central Asia. Nat. Hazards Earth Syst. Sci. 2018, 18. [CrossRef]

24. Erokhin, S.A.; Zaginaev, V.V.; Meleshko, A.A.; Ruiz-Villanueva, V.; Petrakov, D.; Chernomorets, S.S.; Viskhadzhieva, S.K.; Tutubalina, O.; Stoffel, M. Debris flows triggered from non-stationary glacier lake outbursts: The case of the Teztor Lake complex (Northern Tian Shan, Kyrgyzstan). Landslides 2017, 15, 83-98. [CrossRef]

25. Daiyrov, M.; Narama, C.; Yamanokuchi, T.; Tadono, T.; Kääb, A.; Ukita, J. Regional geomorphological conditions related to recent changes of glacial lakes in the Issyk-Kul basin, northern Tien Shan. Geosciences 2018, 8, 99. [CrossRef]

26. Shatravin, V.I. The origin and structure of glacial lakes in Kyrgyz USSR and the mechanism of their outburst. Kazakh Scientific Research Hydrometeorological Institute. Mudflows 1984, 8, 77-83.

27. Narama, C.; Severskiy, I.; Yegorov, A. Current state of glacier changes, glacial lakes, and outburst floods in the Ile Ala-Tau and Kungöy Ala-Too ranges, northern Tien Shan Mountains. Ann. Hokkaido Geogr. 2009, 84, 22-32. [CrossRef]

28. UNEP. Global Outlook for Ice and Snow; UNEP: Nairobi, Kenya, 2007.

29. Erokhin, S. Data Report of Glacial Lakes in 2000-2008. In Inventory of Glacial Lakes; Ministry of Emergency Situations of the Kyrgyz Republic: Bishkek, Kyrgyzstan, 2008. (In Russian)

30. Janský, B.; Šobr, M.; Engel, Z. Outburst flood hazard: Case studies from the Tien-Shan Mountains, Kyrgyzstan. Limnol-Ecol. Manag. Inland Waters 2010, 40, 358-364. [CrossRef]

31. Geological Map of the Kyrgyz SSR of 1:500,000 Scale; Academy of Sciences of the Kyrgyz SSR: Bishkek, Kyrgyzstan, 1987; pp. 38-39.

32. Narama, C.; Shimamura, Y.; Nakayama, D.; Abdrakhmatov, K. Recent changes of glacier coverage in the western Terskey-Alatoo Range, Kyrgyz Republic, using Corona and Landsat. Ann. Glaciol. 2006, 43, 223-229. [CrossRef]

33. Kääb, A.; Huggel, C.; Fischer, L.; Guex, S.; Paul, F.; Roer, I.; Salzmann, N.; Schlaefli, S.; Schmutz, K.; Schneider, D.; et al. Remote sensing of glacier- and permafrost related hazards in high mountains: An overview. Nat. Hazards Earth Syst. Sci. 2005, 5, 527-554. [CrossRef] 
34. Narama, C.; Kääb, A.; Duishonakunov, M.; Abdrakhmatov, K. Spatial variability of recent glacier area changes in the Tien Shan Mountains, Central Asia, using Corona (-1970), Landsat (-2000), and ALOS (-2007) satellite data. Glob. Planet Chang. 2010, 71, 42-54. [CrossRef]

35. Narama, C.; Daiyrov, M.; Tadono, T.; Yamamoto, M.; Kääb, A.; Morita, R.; Ukita, J. Seasonal drainage of supraglacial lakes on debris-covered glaciers in the Tien Shan Mountains, Central Asia. Geomorphology 2017, 286, 133-142. [CrossRef]

36. Chen, X.; Lu, J.; Cai, X.; Li, H.; Yin, S. Geomatics-based method research on capacity calculation of quake lake. Int. J. Remote Sens. 2008, 12, 885-892.

37. Fujita, K.; Suzuki, R.; Nuimura, T.; Sakai, A. Performance of ASTER and SRTM DEMs, and their potential for assessing glacial lakes in the Lunana region, Bhutan Himalaya. J. Glaciol. 2008, 54, 220-228. [CrossRef]

38. Tadono, T.; Shimada, M.; Murakami, H.; Takaku, J. Calibration of PRISM and AVNIR-2 onboard ALOS "Daichi". IEEE Trans. Geosci. Remote Sens. 2009, 47, 4042-4050. [CrossRef]

39. Shimada, M.; Tadono, T.; Rosenqvist, A. Advanced Land Observing Satellite (ALOS) and monitoring global environmental change. Proc. IEEE 2010, 98, 780-799. [CrossRef]

40. Popov, N. Assessment of glacial debris flow hazard in the north Tien-Shan. In Proceedings of the Soviet-China-Japan Symposium and Field Workshop on Natural Disasters, Alma-Ata City, Kazakhstan, 2-17 September 1991; pp. 384-391.

41. Haeberli, W. Frequency and characteristics of glacier floods in the Swiss Alps. Ann. Glaciol. 1983, 4, 85-90. [CrossRef]

42. Huggel, C.; Kääb, A.; Haeberli, W.; Teysseire, P.; Paul, F. Remote sensing based assessment of hazards from glacier lake outbursts: A case study in the Swiss Alps. Can. Geotech. J. 2002, 39, 316-330. [CrossRef]

43. Takaku, J.; Tadono, T. PRISM on-orbit geometric calibration and DEM performance. IEEE Trans. Geosci. Remote Sens. 2009, 47, 4060-4073. [CrossRef]

44. Tadono, T.; Kawamoto, S.; Narama, C.; Yamanokuchi, T.; Ukita, J.; Tomiyama, N.; Yabuki, H. Development and validation of new glacial lake inventory in the Bhutan Himalayas using ALOS 'DAICHI'. Glob. Environ. Res. 2012, 16, 31-40.

45. Sandwell, D.T.; Myer, D.; Mellors, R.; Shimada, M.; Brooks, B.; Foster, J. Accuracy and Resolution of ALOS Interferometry: Vector Deformation Maps of the Father's Day Intrusion at Kilauea. IEEE Trans. Geosci. Remote Sens. 2008, 11, 3524-3534. [CrossRef]

46. Barboux, C.; Delaloye, R.; Lambiel, C. Inventorying of slope movements in Alpine environment using DInSAR. Earth Surface Process. Landf. 2014, 39, 15. [CrossRef]

47. Natsuaki, R.; Nagai, H.; Motohka, T.; Ohki, M.; Watanabe, M.; Thapa, R.B.; Tadono, T.; Shimada, M.; Suzuki, S. SAR interferometry using ALOS-2 PALSAR-2data for the Mw 7.8 Gorkha, Nepal earthquake. Earth Planets Space 2016, 68, 15. [CrossRef]

48. Goldstein, R.M.; Werner, C.L. Radar Ice Motion Interferometry. In Proceedings of the 3rd ERS ESA Symposium, ESA SP, Florence, Italy, 14-21 March 1997; pp. 969-972.

49. Werner, C.; Wegmüller, U.; Strozzi, T.; Wiesmann, A. Gamma SAR and Interferometric Processing Software. In Proceedings of the ERS-ENVISAT Symposium, Gothenburg, Sweden, 16-20 October 2000.

50. Quincey, D.J.; Richardson, S.D.; Luckman, A.; Lucas, R.M.; Reynolds, J.M.; Hambrey, M.J.; Glasser, N.F. Early recognition of glacial lake hazards in the Himalaya using remote sensing datasets. Glob. Planet. Chang. 2007, 56, 137-152. [CrossRef]

51. Barboux, C.; Delaloye, R.; Strozzi, T.; Lambiel, C.; Collet, C. TSX DInSAR data for detecting and monitoring slope motion phenomena in an Alpine periglacial environment at different resolution scales (Western Swiss Alps, Switzerland). In Proceedings of the TerraSAR-X Science Team Meeting, DLR Oberpfaffenhofen, Weßling, Germany, 10-12 June 2013.

52. Obu, J.; Westermann, S.; Bartsch, A.; Berdnikov, N.; Christiansen, H.H.; Dashtseren, A.; Delaloye, R.; Elberling, B.; Etzelmuller, B.; Kholodov, A.; et al. Northern Hemisphere permafrost map based on TTOP modelling for 2000-2016 at $1 \mathrm{~km}(2)$ scale. Earth-Sci. Rev. 2019, 193, 299-316. [CrossRef]

53. Lliboutry, L.; Morales, B.A.; Pautre, A.; Schneider, B. Glaciological problems set by the control of dangerous lakes in Cordillera Blanca, Peru. I. Historical failures of moranic dams, their causes and prevention. J. Glaciol. 1977, 18, 239-254. [CrossRef]

54. Yamada, T. Glacier Lake and Its Outburst Flood in the Nepal Himalaya; Monograph No. 1; Data Center for Glacier Research, Japanese Society of Snow and Ice: Tokyo, Japan, 1998; pp. 1-96. 
55. Fukui, K.; Fujii, Y.; Ageta, Y.; Asahi, K. Changes in the lower limit of mountain permafrost between 1973 and 2004 in the Khumbu Himal, the Nepal Himalayas. Glob. Planet. Chang. 2007, 55, 251-256. [CrossRef]

56. Bolch, T.; Peters, J.; Yegorov, A.; Pradhan, B.; Buchroithner, M.; Blagoveshchensky, V. Identification of potentially dangerous glacial lakes in the northern Tien Shan. Nat. Hazards 2011, 59, 1691-1714. [CrossRef]

57. Kropáček, J.; Neckel, N.; Tyrna, B.; Holzer, N.; Hovden, A.; Gourmelen, N.; Schneider, C.; Buchroithner, M.; Hochschild, V. Repeated glacial lake outburst flood threatening the oldest Buddhist monastery in north-western Nepal. Nat. Hazards Earth Syst. Sci. 2015, 15, 2425-2437. [CrossRef]

58. Worni, R.; Huggel, C.; Stoffel, M.; Pulgarín, B. Challenges of modeling current very large lahars at Nevado del Huila Volcano, Colombia. Bull. Volcanol. 2012, 74, 309-324. [CrossRef]

59. Benn, D.I.; Thompson, S.; Gulley, J.; Mertes, J.; Luckman, A.; Nicholson, L. Structure and evolution of the drainage system of a Himalayan debris-covered glacier, and its relationship with patterns of mass loss. Cryosphere Discuss. 2017, 1-43. [CrossRef]

60. Narama, C.; Daiyrov, M.; Kazehare, S.; Yamamoto, M.; Tadono, T. Glacier Lake Inventory of the Northern Tien Shan-Kyrgyz, Kungoy, and Teskey Ala-Too Ranges; Report of Mountain Research Group of Niigata University; Niigata Printing: Niigata, Japan, 2015.

Publisher's Note: MDPI stays neutral with regard to jurisdictional claims in published maps and institutional affiliations.

(C) 2020 by the authors. Licensee MDPI, Basel, Switzerland. This article is an open access article distributed under the terms and conditions of the Creative Commons Attribution (CC BY) license (http://creativecommons.org/licenses/by/4.0/). 